\title{
Suaeda foliosa Moq. (Caryophyllales: Amaranthaceae) first record of the genus and species for Valparaíso Region, Chile
}

\author{
Lorena Flores-Toro ${ }^{1,2^{*}}$ and Manuel Contreras-López ${ }^{3,4}$
}

\begin{abstract}
Background: The purpose of this paper is to present the finding of Suaeda foliosa in El Yali National Reserve, Chile. With this finding, the southern limit of the distribution is displaced from the current position at $31^{\circ} \mathrm{S}, 300 \mathrm{~km}$ southward.

Findings: In this work, we found this species on the banks of the Colejuda lagoon, $33^{\circ} 45^{\prime} \mathrm{S}$, which belongs to a body of hypersaline seasonal water found inside the protected area distinguished as a Ramsar site (No. 878). The determination of the genus and species was achieved by comparing with herbarium material deposited in the National Herbarium SGO Natural History Museum in Santiago de Chile. Once we identified the species, the collected material was deposited in the referred Herbarium (SGO 163975). pH, salinity, and conductivity of the water column and soil adjacent the three protected lagoons are compared, discussing the unique conditions of the lagoon Colejuda that may explain the presence of $\mathrm{S}$. foliosa only in their environment and not in other water bodies.

Conclusions: It can be concluded that El Yali wetland system harbors the S. foliosa southernmost population of the Americas.
\end{abstract}

Keywords: Coastal wetland; Ramsar site; Displacement of limit of the distribution

\section{Findings}

The gender Suaeda Forssk. ex Scop. consists of roughly 110 species growing in saline, littoral, or Andean steppe environments throughout the world. Five different species are found in Chile, three of them are native and two are endemic (Teillier 1996; Zuloaga et al. 2009). The species described in Chile are as follows: Suaeda nesophila I.M. Johnst., they are endemic in two islands, San Félix and San Ambrosio. These islands belong to the Islas Desventuradas complex (Teillier 1996). Suaeda multiflora Phil. is endemic in the Atacama Region and has been officially declared vulnerable (Squeo et al. 2008; MINSEGPRES 2011). Suaeda argentinensis A. Soriano and Suaeda patagonica Speg. are both native in Chile and Argentina; they are located in Chile, cited in Tierra del Fuego (Moore 1983). Finally, Suaeda foliosa Moq. is native in Chile, Peru, and Bolivia (Muñoz-Schick et al. 2001).

In Bolivia, S. foliosa is an important native forage for livestock feed. It is the dominant element of the plant communities inhabiting the seasonal endemic peatlands of the Altiplano. It lives in the fluvial-lacustrine salt flats and beaches located at margins of salt lakes and flood plains of the rivers and dry semiarid highlands (Rocha-Olivio 2013).

In Peru and Chile, S. foliosa inhabits the coastal desert; it is part of the floristic cast of Lomas vegetation present in both countries (Muñoz-Schick et al. 2001; Dillon et al. 2011). In this context, S. foliosa finds its northern limit in Loma Mongon (9 $37^{\prime} \mathrm{S}$ ), located $352 \mathrm{~km}$

\footnotetext{
* Correspondence: Iflorestoro@gmail.com

${ }^{1}$ Facultad de Ecología y Recursos Naturales, Universidad Andrés Bello, Calle

República No 252, Santiago, Chile

${ }^{2}$ Instituto de Geografía, Pontificia Universidad Católica de Valparaíso, Avenida

Brasil 2241, Valparaíso, Chile

Full list of author information is available at the end of the article
}

\section{Springer}

(c) 2015 Flores-Toro and Contreras-López; licensee Springer. This is an Open Access article distributed under the terms of the Creative Commons Attribution License (http://creativecommons.org/licenses/by/4.0), which permits unrestricted use, distribution, and reproduction in any medium, provided the original work is properly credited. 


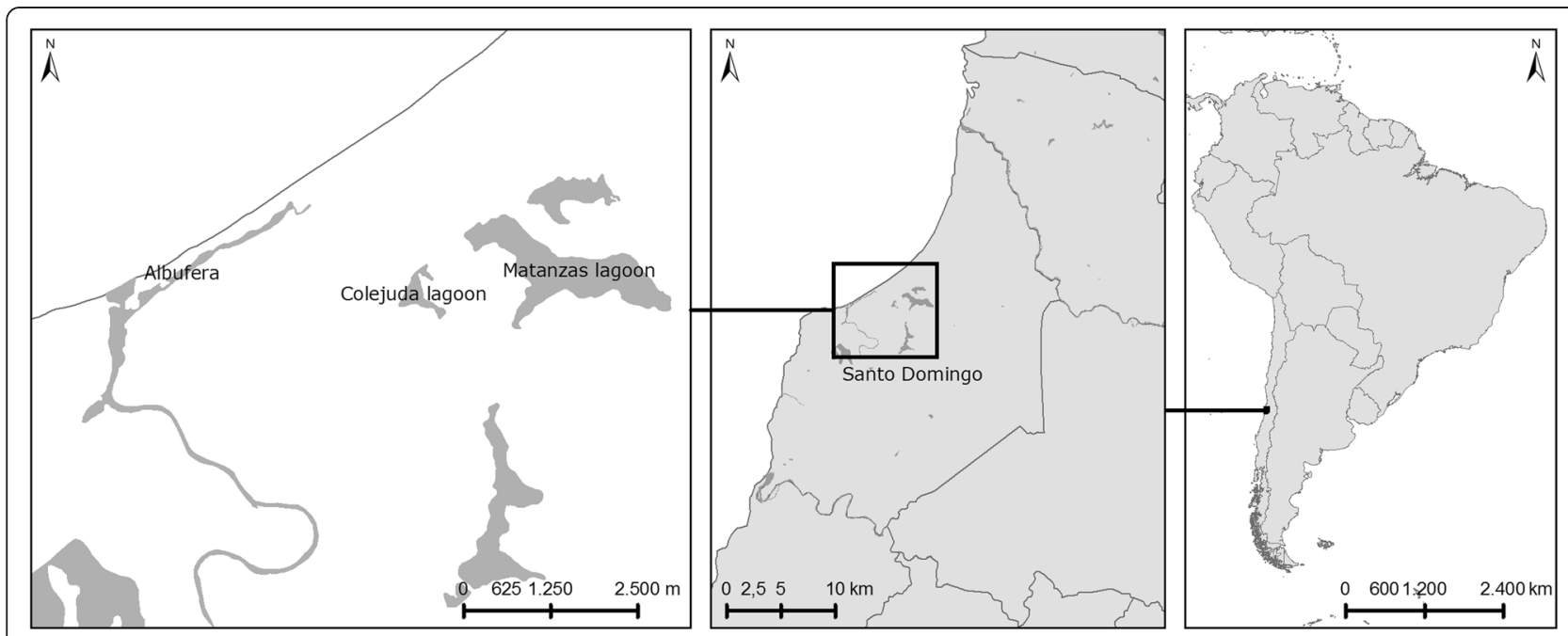

Figure 1 Map of EYNR and its location on the southern coast of the Valparaíso Region and South American context. The site where S. foliosa was found is displayed.

north of Lima (Peru), and its southern limit known so far is $31^{\circ} \mathrm{S}$, in Coquimbo Region, Limarí Province, Ovalle County (Marticorena et al. 2001; Leiva-González et al. 2008; Zuloaga et al. 2009).

In this note, we present the finding of S. foliosa on the banks of the Colejuda lagoon $\left(33^{\circ} 45^{\prime} \mathrm{S}\right.$ to $\left.71^{\circ} 41^{\prime} \mathrm{W}\right)$, located on the coast of the Santo Domingo County, San Antonio Province, Valparaíso Region (Figure 1). The Colejuda lagoon is one of the three bodies of water protected within El Yali National Reserve (EYNR), which is a Ramsar site of international significance (Fariña et al. 2012).

\section{Material examined}

CHILE; Atacama Region; Bahía Inglesa; 01-XI-1991; M. Muñoz, S. Teillier, I. Meza 123949 (SGO). CHILE;
Atacama Region; Road to Carrizal Bajo; 02-XI-1991; M. Muñoz, S. Teillier, I. Meza 123948 (SGO). CHILE; Atacama Region; km 556, Norte Llano Los Choros; 16X-1992; M. Muñoz 131510 (SGO). CHILE; Coquimbo Region; Road located Eastward of Universidad Católica del Norte; 03-XI-1991; M. Muñoz, S. Teillier, I. Meza 123947 (SGO).

\section{New record}

Between May and August 2014, samples of a particular species of plant were collected and photographed in the margins of Colejuda lagoon. Relevant taxonomic literature was used to ultimately determine that the sample belonged to the genus Suaeda. Subsequently, using an identification key to the recognized taxa of Suaeda occurring in Chile (Teillier 1996) and the SGO Herbarium

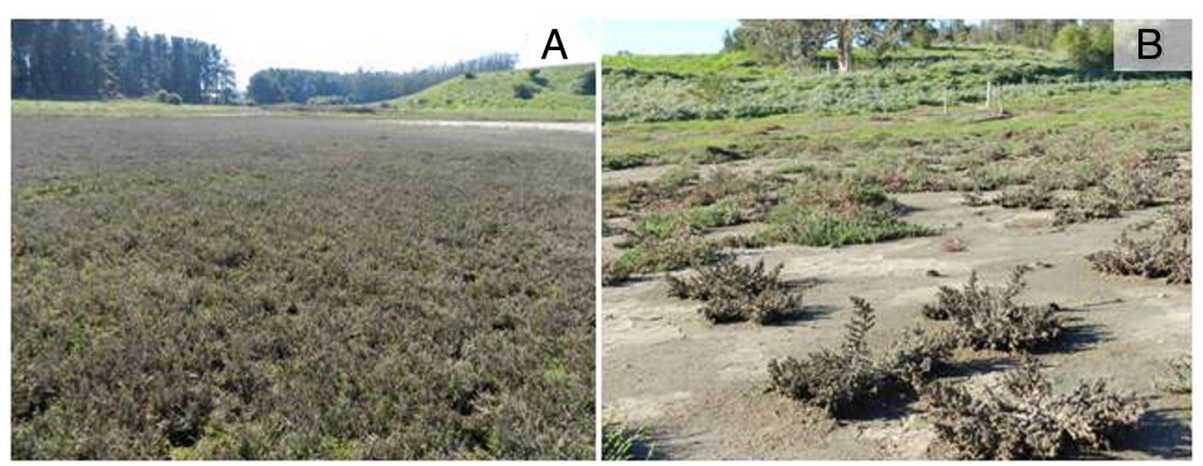

Figure 2 Halophytic meadow of S. foliosa and S. neei occupying entire margin of Laguna Colejuda is shown in foreground. (A) Northwest shore, (B) southern shore. 
Table 1 Comparison of the environmental conditions for the three protected lagoons of EYNR

\begin{tabular}{lllll}
\hline & \multicolumn{2}{l}{ Body of water } & & \\
\cline { 2 - 4 } Abiotic factors & Albufera Lagoon & Matanza Lagoon & Colejuda Lagoon & Source \\
\hline Surface & 16 hectares & 190 hectares & 20 hectares & - \\
Height above mean sea level & 0 & $8 \mathrm{~m}$ & $7 \mathrm{~m}$ & Unpublished observations \\
Regime & Permanent littoral lagoon & Permanent lagoon & Seasonal lagoon & - \\
pH of the water column & 8.5 to 8.9 & 8.4 to 9.5 & 8.4 to 8.9 & Figueroa et al. (2009) \\
pH soil & 7.4 & 6.8 to 8.1 & 7.9 & Unpublished observations \\
Salinity of the water column & 37 & 5 to 12 & 151 & Unpublished observations \\
Conductivity of the water column & 65,700 to $65,800 \mathrm{mS} / \mathrm{cm}$ & $8,990 \mathrm{mS} / \mathrm{cm}$ & $183,000 \mathrm{mS} / \mathrm{cm}$ & Figueroa et al. (2009) \\
Conductivity of the soil & $313 \mathrm{dS} / \mathrm{cm}$ & $216 \mathrm{dS} / \mathrm{cm}$ & $967 \mathrm{dS} / \mathrm{cm}$ & Unpublished observations \\
\hline
\end{tabular}

at the National Museum of Natural History in Santiago de Chile, it was determined that the species collected corresponded to $S$. foliosa Moq., that belongs to the family Amaranthaceae. Once the species was identified, the collected material was deposited in the mentioned herbarium (SGO 163975).

S. foliosa as well as with Sarcocornia neei forms a ring of halophytic vegetation growing around the margins of Colejuda lagoon with a width ranging between 5 and $300 \mathrm{~m}$ (Figure 2). In the lagoon Matanza, isolated communities with few individuals were recorded. However, in the other lagoon, 'Albufera', a ring of halophytic vegetation described by Fariña et al. (2009) was observed, but it contains no $S$. foliosa. This situation may be explained by the large differences among the abiotic factors of the three lagoons (see Table 1). In fact, high values of conductivity and salinity in the water column at Colejuda lagoon seem to maintain mesosaline conditions throughout all seasons of the year. In addition, our results appear to be consistent with the analysis of soil conductivity, which almost triples the records on the banks of the other water bodies (Table 1).

The uniqueness of the Colejuda lagoon with respect to the other two bodies of water is reflected in the parameters shown in Table 1. It is known that the complexity of this ecosystem is an expression of the variability and heterogeneity of the environmental conditions, in particular the hydrochemistry (VidalAbarca et al. 2011). These conditions are favorable for the colonization of $S$. foliosa in Colejuda lagoon and also may explain the absence on the banks of the other nearby water bodies. This species thrives in soil with high levels of salt and metals (Rocha-Olivio 2013), as is the case of Colejuda lagoon.

The presence of $S$. foliosa in El Yali wetland system constitutes the first record of this species for the region of Valparaíso and allows extension of distributional ranges about $300 \mathrm{~km}$ south. Therefore, the EYNR becomes the phytogeographical point of reference for hosting the southernmost population of $S$. foliosa in South America.

\section{Competing interests}

The authors declare that they have no competing interest.

\section{Authors' contributions}

MCL suggested vising the El Yali National Reserve. LFT found and identified the species, corroborated in the museum, and wrote the first manuscript. $\mathrm{MCL}$ enriched the discussion with $\mathrm{pH}$ data, conductivity, and salinity of water and soil. Both authors read and approved the final manuscript.

\section{Acknowledgements}

Fondo de Desarrollo Disciplinario de la Facultad de Ingeniería-UPLA, ParksCanada, MMA, CONAF, G. Rojas-Villegas, Herbario (SGO) enabled consultation to the collection Suaeda. C Mizobe, H. Gallardo, I. Velásquez, J. Meza, V. Meza, P. Huerta, E. Brito, P. Winckler, E. Quiroga, and M. Guevara are also acknowledged.

\section{Author details}

${ }^{1}$ Facultad de Ecología y Recursos Naturales, Universidad Andrés Bello, Calle República No 252, Santiago, Chile. ${ }^{2}$ Instituto de Geografía, Pontificia Universidad Católica de Valparaíso, Avenida Brasil 2241, Valparaíso, Chile. ${ }^{3}$ Facultad de Ingeniería, Universidad de Playa Ancha, Av. Carvallo 270, Valparaíso, Chile. ${ }^{4}$ Centro de Estudios Avanzados, Universidad de Playa Ancha, Traslaviña 450, Viña del Mar, Chile.

Received: 14 October 2014 Accepted: 16 January 2015

Published online: 30 January 2015

\section{References}

Dillon M, Leiva-González S, Zapata-Cruz M, Lezama-Asencio P, Quipuscoa-Silvestre V (2011) Floristic checklist of the Peruvian lomas formations. Arnaldoa 18(1):07-32 Fariña JM, Silliman BR, Bertness MD (2009) Can conservation biologists rely on established community structure rules to manage novel systems? ... Not in salt marshes. Ecol Appl 19(2):413-422. doi:10.1890/07-1000.1

Fariña JM, Bertness MD, Silliman B, Aragoneses N, Gayo E (2012) Historia natural y patrones ecológicos del humedal costero El Yali, Chile Central. In: Fariña MJ, Camaño A (ed) Humedales costeros de Chile. Ediciones UC, Santiago de Chile

Figueroa R, Suarez M, Andreu A, Ruiz V, Vidal-Abarca M (2009) Caracterización Ecológica de Humedales de la Zona Semiárida en Chile Central. Gayana (Concepc) 73(1):76-94. doi:10.4067/S0717-65382009000100011

Leiva-González S, Zapata-Cruz M, Galloso-Bazán G, Lezama-Asencio P, QuipuscoaSilvestre V, Dillon M (2008) Diversidad florística de la Loma Mongón, Provincia Casma, Departamento Ancash, Perú. Arnaldoa 15(1):45-62

Marticorena C, Squeo FA, Arancio G, Muñoz M (2001) Catálogo de la flora vascular de la IV Región de Coquimbo. In: Squeo FA, Arancio G, Gutiérrez JR (ed) Libro Rojo de la flora nativa y de los Sitios prioritarios para su conservación: Región de Coquimbo. Ediciones Universidad de La Serena, La Serena 
MINSEGPRES (2011) Decreto Supremo No33, promulgado el 07 de septiembre de 2011; publicado en el Diario Oficial el 27 de febrero de 2012.

Moore DM (1983) Flora of Tierra del Fuego. Oswestry Anthony Nelson, England, Missouri Botanical Garden, USA

Muñoz-Schick M, Pinto R, Mesa A, Moreira-Muñoz A (2001) "Oasis de neblina" en los cerros costeros del sur de lquique, región de Tarapacá, Chile, durante el evento El Niño 1997-1998. Revista Chilena de Historia Natural 74(2):389-405. doi:10.4067/S0716-078X2001000200014

Rocha-Olivio O (2013) Diagnóstico de la zona montañosa de Bolivia: Fortalecimiento de la gestión participativa para el desarrollo sostenible de los Andes (documento preliminar). FAO, BMI, Ministerio de Relaciones Exteriores, Bolivia Squeo FA, Arancio G, Gutiérrez JR (2008) Libro Rojo de la Flora Nativa y de los Sitios Prioritarios para su Conservación: Región de Atacama. Ediciones Universidad de La Serena, La Serena, Chile

Teillier S (1996) Revisión de las especies de Suaeda (Chenopodiaceae) de Chile. Revista Gayana Botanica 53:265-276

Vidal-Abarca M, Suárez M, Figueroa R, Enríquez M, García V, Domínquez C, Arce M (2011) Caracterización hidroquímica del complejo de humedales El Yali, Chile Central. Limnetica 30(1):43-58

Zuloaga F, Morrone O, Belgrano M (2009) Catálogo de las Plantas Vasculares del Cono Sur. Instituto Darwinion, Argentina. http://www.darwin.edu.ar/Proyectos/ FloraArgentina/Especies.asp. Accessed 27 Jan 2015

\section{Submit your manuscript to a SpringerOpen ${ }^{\circ}$} journal and benefit from:

- Convenient online submission

- Rigorous peer review

- Immediate publication on acceptance

- Open access: articles freely available online

- High visibility within the field

- Retaining the copyright to your article

Submit your next manuscript at $\gg$ springeropen.com 